\title{
PERSPECTIVE
}

\section{A basic scientist's odyssey in nutrition}

P Trayhurn

Obesity Biology Unit, University of Liverpool, Liverpool, UK and Clore Laboratory, University of Buckingham, Buckingham, UK

Running title: An odyssey in nutrition

Correspondence should be addressed to:

Emeritus Professor Paul Trayhurn, FRSE

Clore Laboratory

University of Buckingham

Hunter Street

Buckingham MK18 1EG

$U K$

Email: $\quad$ p.trayhurn@liverpool.ac.uk

Fax: $\quad$ +441280820135 
Many whose research career has been in nutrition have found themselves in the area both by accident and without formal training - and this is very much so in my case. I am a basic scientist motivated principally by the desire to understand physiological systems. My first degree was in Physiology \& Biochemistry, followed by a doctorate in Biochemistry. Although my doctoral studies were on the metabolism of the lens under the supportive supervision of Ruth van Heyningen, the Nuffield Laboratory of Ophthalmology in Oxford where I studied had as its head Antoinette Pirie, one of whose interests was the impact of vitamin A deficiency on xerophthalmia. To that extent I had some early, albeit tangential, exposure to nutrition.

My doctoral studies serendipitously brought me into contact with the legendary Nobelist, Sir Hans Krebs. After his retirement from the Whitley Chair of Biochemistry at Oxford, he established a Metabolic Research Unit in the Radcliffe Infirmary close to where my lab was based. Each time I returned from the local slaughterhouse with cattle eyes for my work, Sir Hans would personally come to collect the vitreous humour as a culture medium which I would transfer to him in a considerable state of awe.

\section{INTO NUTRITION}

My formal move into nutrition, which followed post-doctoral posts in Strasbourg on the retina and then back in Oxford on the lens, began in 1975 when I joined the Energy Group being established by Philip James at the MRC Dunn Nutritional Laboratory in Cambridge. The Dunn, with its distinguished history, was a remarkable place. It was full of highly talented scientists, resources appeared unlimited, and there was considerable freedom to go where the science demanded. Colleagues from the Dunn have remained my life-long friends, especially Prakash Shetty and David Fraser both of whom became god-parents to our eldest son.

My research in Cambridge initially centred on using animal models to explore the energetics of obesity and we set-up colonies of $o b / o b$ mice to represent the extreme form of the disorder. Detailed energy balance studies clearly demonstrated that obesity can develop in the absence of hyperphagia through a reduction in energy expenditure, and this quickly led to an interest in thermoregulation and thermogenesis. ${ }^{1-3}$ When we began to explore the biochemical basis of reduced thermogenesis in obesity, brown adipose tissue (BAT) was emerging as the key thermogenic organ through work by Foster and Frydman in Ottawa. ${ }^{4-5}$ From 1978 onwards, brown fat became my central interest and our group was one of the pioneers, alongside Jean Himms-Hagen (Ottawa) and Michael Stock and Nancy Rothwell (London), of the link between BAT, energy metabolism and obesity. 
At the Dunn, my team demonstrated substantial changes in the thermogenic activity of BAT in a range of energetically demanding situations, including lactation, overfeeding and fasting - as well as in different animal obesities. Our key contributions included identifying a major suppression of BAT thermogenesis in lactation, which helps meet the energy costs of milk production. ${ }^{6}$ We also showed that brown fat is a major site of lipogenesis, particularly in mice acclimated to the cold where it is considerably more important than the liver ${ }^{7}$, and with my student Stewart Mercer we established that the development of insulin resistance severely compromises the thermogenic activity of BAT. ${ }^{8}$ Another student, Anne Goodbody, and I had a inspirational collaboration with Nancy Rothwell and Mike Stock, in which we showed that the diet-induced thermogenesis that they had recorded in rats overfed on a 'cafeteria diet', and which they had linked to brown fat, ${ }^{9}$ was associated with an activation of the proton conductance pathway in BAT mitochondria. ${ }^{10}$ This collaboration featured in a BBC Horizon television programme on brown fat and obesity in 1979.

In addition to $a b / o b$ mice, we established colonies of other obese mutants, including Zucker $f a / f a$ rats and $d b / d b$ mice, and also maintained both golden and Djungarian hamsters. This was on the August Krogh principle that "for many problems there is an animal on which it can be most conveniently studied". The facility to maintain multiple animal models at the Dunn without charge to the investigator was remarkable - as I discovered when I moved to the University of Alberta (Canada) in 1986 as Professor and Heritage Scholar in Nutrition \& Metabolism and received my first billing for a colony of $o b / o b$ mice. The move to Alberta came as a consequence of the recruitment being undertaken by the two major Universities in the Province, funded through the Alberta Heritage Foundation for Medical Research which had been established from the oil revenues. At that period, and as a scientist in his mid-30s, being offered several hundred thousand dollars to set up a new lab was irresistible. Brown fat remained my core interest in Alberta, and I took the opportunity to extend a comparative approach, including exploring thermogenesis in the tissue during the profound seasonal obesity and hibernation cycles of ground squirrels. ${ }^{11}$

By chance, oil centres have been a feature of some of my subsequent affiliations. After Alberta, I moved to the Rowett Research Institute in Aberdeen - the oil capital of Europe - as Head of the Division of Biomedical Sciences. My other oil-linked association came much later when in 2014 I was privileged to be appointed to a Distinguished Scientist Fellowship at King Saud University, Saudi Arabia, funded through the Kingdom's oil wealth.

During the early years at the Rowett my focus continued to be on BAT, again with a comparative perspective which included studies on the tissue in the newborn of large precocial 
species, particularly goats and reindeer. These studies explored the rapid post-natal transition of BAT to white fat in these animals. Working on species of agricultural importance was one of the multiple opportunities afforded by the Rowett. Another was the wide range of collaborative possibilities, one of which resulted in a serendipitous observation with John Arthur that selenium deficiency leads to a fall in the ability of rats to respond to cold through activation of $\mathrm{T}_{3}$ production in $\mathrm{BAT}^{12}$

For some while I had been considering moving on from BAT, primarily as a consequence of the then prevailing view that the tissue was of little relevance to human energetics; this perspective has changed markedly in recent years following studies employing fluorodeoxyglucose positron emission tomography. ${ }^{13}$ Just before Christmas 1994 my research programme switched abruptly to the endocrine role of white adipose tissue (WAT) following the cloning of the $o b$ gene (Lep) and the discovery of leptin. ${ }^{14}$ I vividly remember receiving the issue of Nature of 1 December 1994 in which this work was published, and within days my group had produced probes to measure the expression of the $o b$ gene. Six months later our first paper on leptin was published in which Vernon Rayner and I showed that expression of the $o b$ gene was nutritionally regulated, fasting leading to a marked suppression of expression which was rapidly reversed on refeeding. ${ }^{15}$ One of the other highlights of our leptin work was the demonstration that expression of the gene is strongly suppressed by activation of the sympathetic nervous system, this operating via $\beta_{3}$-adrenoceptors. ${ }^{16-17}$ We also produced the first ELISA for the hormone. $^{18}$

The rapidity with which I moved to work on leptin has a simple explanation. Some two years earlier a consortium of us in the UK, which included Mike Stock, had tried to obtain funding to identify the defective genes in obese mutants, but were unsuccessful with reviewers noting that since researchers at the Rockefeller were well advanced in the same goal it was unlikely that we would be competitive. This view proved quite correct, and my response was that I would wait until the key gene(s) had been identified and then explore the physiology of the encoded protein(s).

For several years, leptin was the subject of intense activity by my group. However, unsurprisingly many others quickly focused on such an important factor and hundreds of papers were soon being published on leptin each year. My philosophy has been that if an area becomes quasi-industrial in scale it is appropriate to move on since it is then difficult to make a substantive contribution. For the next decade the broader concept of adipokines beyond leptin became my main interest, initially in the Rowett and then subsequently at the University of Liverpool, punctuated by a brief sojourn at the Institute of Nutrition, University of Oslo, as part 
of their internationalisation. Leaving Aberdeen was a wrench, and I consider myself extremely fortunate to have been one of the handful of scientists who have worked at two such internationally acclaimed nutritional research centres as the Dunn and the Rowett. I am also fortunate to have been in two of the world's great academic centres - Oxford and Cambridge.

At Liverpool, as in Alberta, I was appointed primarily for research with teaching being through the supervision of Master's and Doctoral students. The central interests of our work in Liverpool were on the discovery of novel adipokines from human fat cells (including, with Chen Bing, the lipolytic factor zinc- $\alpha_{2}$-glycoprotein ${ }^{19}$ - a highly abundant protein secreted by adipocytes) and the inflammation that develops in WAT as it expands in obesity, this expansion underpinning the development of obesity-associated disorders.

A question that greatly intrigued me was why inflammation occurs in WAT as adipocytes expand. In 2004 we proposed that the answer might be hypoxia, adipocytes being oxygendeprived as they enlarge and become distant from the vasculature, this leading to a series of metabolic adaptations involving the recruitment of the key hypoxia-inducible transcription factor, HIF-1..$^{20-21}$ The studies that Stuart Wood, Bohan Wang and I conducted over the following few years demonstrated pervasive effects of hypoxia on human adipocytes - from alterations in the expression of $>1300$ genes to substantial changes in the production of key adipokines such as leptin, and major increases in glucose utilisation and disposal (Figure 1). ${ }^{22-23}$

The ways in which variations in $\mathrm{O}_{2}$ level modulate cellular function have continued to fascinate me, and I have recently argued that $\mathrm{O}_{2}$ is a "forgotten macronutrient" - an overlooked dimension of nutrition (Figure 2). ${ }^{23-24}$ This has been a particular interest following my retirement from Liverpool, after which I have held 'post-retirement' part-time positions at the University of Buckingham, including as Dean of Research Strategy.

\section{PERSPECTIVES}

Science, as with other areas of academia, functions as a 'prestige-based economy' with the capital of reputation mattering more than financial rewards. I am fortunate to have received some recognition: my scientific work has been highly cited, I was elected to Fellowship of the Royal Society of Edinburgh (National Academy of Scotland) in 1997, and in 2008 received the Wassermann Award for lifetime contributions to obesity research from the European Association for the Study of Obesity. Particular satisfaction came from my role as Editor-inChief of the British Journal of Nutrition, and I was delighted that during my tenure (1999-2005) the rate of submissions more than doubled. 
Over a number of years I have represented nutrition in Research Councils and other funding bodies, as well as in Learned Societies and various Scientific Committees, both in the UK and internationally. But I have often seen myself as being towards the periphery of nutrition, and not only because of being a basic scientist who entered the field by chance. One reason is that my work on energy metabolism and obesity has concerned total intake/expenditure and adipose tissue function, rather than nutrition per se. Another is that I have remained uncomfortable with the evangelism that can flavour nutritional discourse in some quarters, especially in matters of public health.

This leads me to science as a social construct. When in the 1980s I first became aware of this concept my response was of disbelief. I held the customary view that science was dispassionate and objective, with the choice of problem and approach being driven entirely by scientific factors. However, working on obesity has emphasised that how we view a scientific problem is coloured by social and cultural attitudes. When I began in obesity research the core paradigm was 'gluttony and sloth', and those of us exploring metabolic parameters were running counter to the prevailing cultural view centred on personal choice and responsibility. However, over the past 40 years views on causality have switched to genetics and particularly to the 'obesogenic environment'. While there is undoubtedly a genetic predisposition, and the environment does facilitate over-consumption and encourage sedentary behaviours, this has been accompanied by the implication that the individual has minimal control over, or responsibility for, their weight. This parallels development of the presumption that solutions to most problems lie firmly with Governments.

The climate in which science is conducted has changed markedly during my career, and this also reflects evolving societal attitudes. There is more managerialism, more pressure to deliver results, and Governments have become directly involved. One of the biggest changes is the importance now attached to the status of the journal when selecting where to publish, particularly the 'impact factor'. In some countries an immediate financial reward is given for papers in high impact journals, which may amount to tens of thousands of dollars for a publication in Nature or Science. There is a real risk that such rewards will fuel scientific misconduct. When I started in the Dunn, while a paper in Nature was regarded as good, it was not career-changing in the way it is now, and what was required in terms of content was much less extensive.

My first Nature paper, which was my earliest nutrition article, demonstrated that a thermogenic defect in $o b / o b$ mice precedes the development of obesity, and that the impaired temperature regulation of pre-obese $o b / o b$ animals provides a simple means of identifying the 
mutants before the phenotype is manifested. ${ }^{1}$ However, the paper contained just two Figures with rectal temperature curves (Figure 3), together with a Table showing how successful we were in identifying genotype - and the sole tool employed was a rectal thermistor probe. If so little information was submitted today, based on such simple measurements, the rejection email would arrive within minutes.

\section{CONCLUDING COMMENTS}

Nutrition is an integrative science. However, it has traditionally been segmented by species whether farm, companion or laboratory animals, or humans - by the level of organisation (molecular/cellular, physiological/whole-body, population, public health) and between observational and mechanistic approaches, and frequently these have not communicated with one another. Gaining mechanistic insight is critical, and there is much to be gained by a comparative approach. Indeed, advances in human nutrition will continue to be dependent on knowledge obtained from other species.

Nutrition must also harness new scientific concepts and technologies as soon as they arise, and indeed be at the forefront of developments in the biosciences. The discipline was slow to embrace the genetic revolution, and the subsequent opportunities provided by 'omics'. Nevertheless, they are now part of nutritional science and nutrigenomics is an established field. Delay in embracing new dimensions slows development and risks reducing the attractiveness of nutrition to talented young scientists. Finally, it is essential to follow what one believes in - and to be willing to challenge embedded scientific, social and cultural assumptions.

\section{Acknowledgements}

I thank the many colleagues, students and collaborators with whom I have worked and apologise that for reasons of space most are unnamed. I would also like to warmly acknowledge the unfailing support of my wife Deborah, not least for her willingness to embrace our multiple family moves as great adventures (“invitations are so compelling!”). 


\section{References}

1 Trayhurn P, Thurlby PL, James WPT. Thermogenic defect in pre-obese $o b / o b$ mice. Nature 1977; 266: 60-62.

2 Thurlby PL, Trayhurn P. The role of thermoregulatory thermogenesis in the development of obesity in genetically obese $(o b / o b)$ mice pair-fed with lean siblings. Br J Nutr 1979; 42: 377-385.

3 Trayhurn P, James WPT. Thermoregulation and non-shivering thermogenesis in the genetically obese (ob/ob) mouse. Pflïgers Archiv Eur J Physiol 1978; 373: 189-193.

4 Foster DO, Frydman ML. Nonshivering thermogenesis in the rat. II. Measurements of blood flow with microspheres point to brown adipose tissue as the dominant site of the calorigenesis induced by noradrenaline. Can J Physiol Pharmacol 1978; 56: 110-122.

5 Foster DO, Frydman ML. Tissue distribution of cold-induced thermogenesis in conscious warm- or cold-acclimated rats re-evaluated from changes in tissue blood flow: the dominant role of brown adipose tissue in the replacement of shivering by non-shivering thermogenesis. Can J Physiol Pharmacol 1979; 57 257-270.

6 Trayhurn P, Douglas JB, McGuckin MM. Brown adipose tissue thermogenesis is 'suppressed' during lactation in mice. Nature 1982; 298: 59-60.

7 Trayhurn P. Fatty acid synthesis in mouse brown adipose tissue: the influence of environmental temperature on the proportion of whole-body synthesis in brown adipose tissue and the liver. Biochim Biophys Acta 1981; 664: 549-560.

8 Mercer SW, Trayhurn P. The development of insulin resistance in brown adipose tissue may impair the acute cold-induced activation of thermogenesis in genetically obese $(o b / o b)$ mice. Biosci Rep 1984; 4: 933-940.

9 Rothwell NJ, Stock MJ. A role for brown adipose tissue in diet-induced thermogenesis. Nature 1979; 281: 31-35.

10 Brooks SL, Rothwell NJ, Stock MJ, Goodbody AE, Trayhurn P. Increased proton conductance pathway in brown adipose tissue mitochondria of rats exhibiting diet-induced thermogenesis. Nature 1980; 286: 274-276.

11 Milner RE, Wang L, Trayhurn P. Brown fat thermogenesis during hibernation and arousal in Richardson's ground squirrel. Am J Physiol Reg Integr Comp Physiol 1989; 256: R42-48.

12 Arthur JR, Nicol F, Beckett GJ, Trayhurn P. Impairment of iodothyronine 5'-deiodinase activity in brown adipose tissue and its acute stimulation by cold in selenium deficiency. Can J Physiol Pharmacol 1991; 69: 782-785. 
13 Nedergaard J, Cannon B. The changed metabolic world with human brown adipose tissue: therapeutic visions. Cell Metab 2010; 11: 268-272.

14 Zhang YY, Proenca R, Maffei M, Barone M, Leopold L, Friedman JM. Positional cloning of the mouse obese gene and its human homolog. Nature 1994; 372: 425-432.

15 Trayhurn P, Thomas MEA, Duncan JS, Rayner DV. Effects of fasting and refeeding on ob gene-expression in white adipose-tissue of lean and obese $(o b / o b)$ mice. FEBS Lett 1995; 368: $488-490$.

16 Trayhurn P, Duncan JS, Rayner DV. Acute cold-induced suppression of ob (obese) geneexpression in white adipose-tissue of mice - mediation by the sympathetic system. Biochem J 1995; 311: 729-733.

17 Trayhurn P, Duncan JS, Rayner DV, Hardie LJ. Rapid inhibition of ob gene expression and circulating leptin levels in lean mice by the $\beta_{3}$-adrenoceptor agonists BRL 35135A and ZD2079. Biochem Biophys Res Commun 1996; 228: 605-610.

18 Hardie LJ, Rayner DV, Holmes S, Trayhurn P. Circulating leptin levels are modulated by fasting, cold exposure and insulin administration in lean but not Zucker $(f a / f a)$ rats as measured by ELISA. Biochem Biophys Res Commun 1996; 223: 660-665.

19 Bing C, Bao Y, Jenkins J, Sanders P, Manieri M, Cinti S et al. Zinc- $\alpha_{2}$-glycoprotein, a lipid mobilising factor, is expressed in adipocytes and upregulated in mice with cancer cachexia. Proc Natl Acad Sci USA 2004; 101: 2500-2505.

20 Trayhurn P, Wood IS. Adipokines: Inflammation and the pleiotropic role of white adipose tissue. BrJ Nutr 2004; 92: 347-355.

21 Trayhurn P, Wang B, Wood IS. Hypoxia in adipose tissue: a basis for the dysregulation of tissue function in obesity? BrJ Nutr 2008; 100: 227-235.

22 Trayhurn P. Hypoxia and adipose tissue function and dysfunction in obesity. Physiol Rev 2013; 93: 1-21.

23 Trayhurn P. Hypoxia and adipocyte physiology: implications for adipose tissue dysfunction in obesity. Ann Rev Nutr 2014; 34: 207-236.

24 Trayhurn P. Oxygen - the forgotten nutrient. J Nutr Sci 2017; 6: e47 1-4. 


\section{Legends to Figures}

Figure 1. Schematic representation of the cellular responses to hypoxia by human adipocytes $\left(\right.$ modified from $\left.{ }^{24}\right)$ angpt14, angiopoietin-like protein-4; FA, fatty acid; GLUT1, facilitative glucose transporter 1; HIF-1, hypoxia-inducible factor-1; MCT1, monocarboxylate transporter-1; MMP, matrix metalloproteinases; MT-3, metallothionein-3; PAI-1, plasminogen activator inhibitor-1; PPAR $\gamma$, peroxisome proliferator-activated receptor; TF, transcription factors (additional to HIF-1); UCP2, uncoupling protein-2; VEGF, vascular endothelial growth factor.

Figure 2. Oxygen as a forgotten nutrient. Article proposing that oxygen is a macronutrient which should be considered part of nutritional science. ${ }^{24}$

Figure 3. Figures from Nature paper published in 1977 showing defective thermoregulation/thermogenesis in pre-obese $o b / o b$ mice. ${ }^{1}$ Simplicity can be potent. 


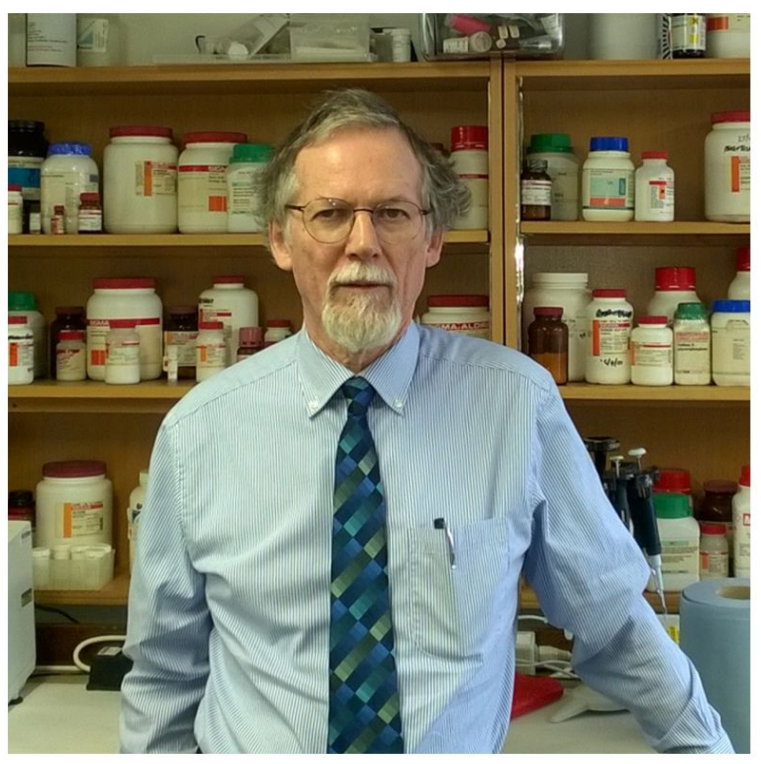




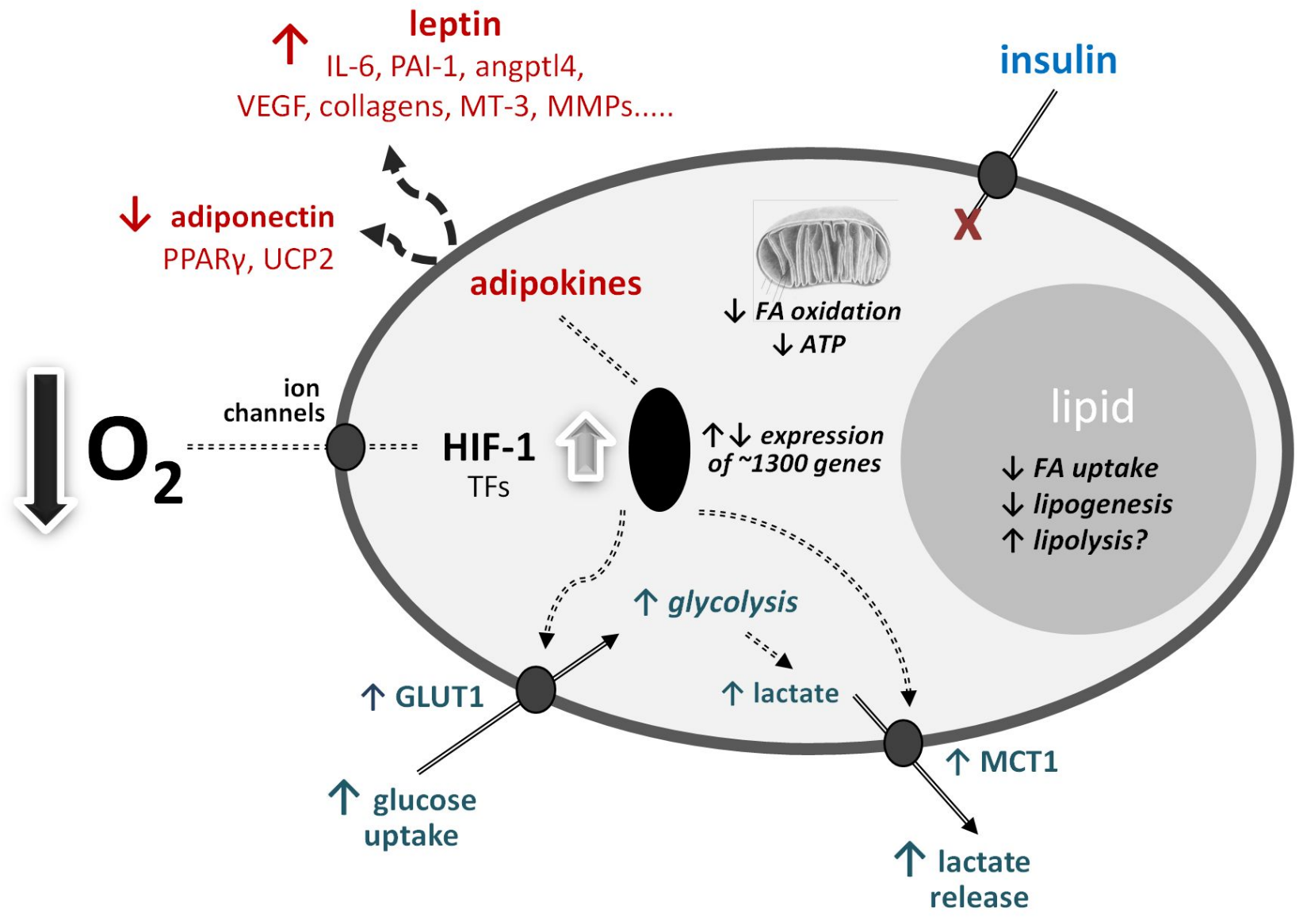




\section{JOURNAL OF NUTRIIIONAL SGIENCE}

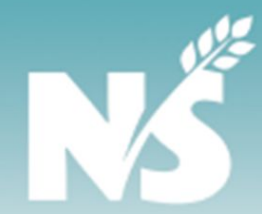

\section{PERSPECTIVES IN NUTRITIONAL SCIENCE}

Oxygen - the forgotten nutrient

Paul Trayhum ${ }^{12}$

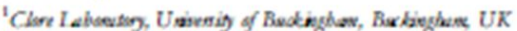

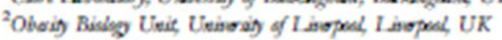

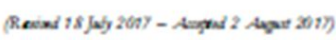

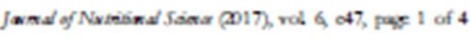

dostoson/ine 2017.53

Abstract

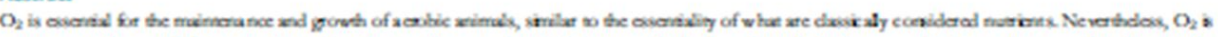

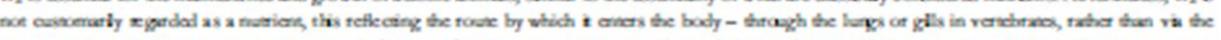

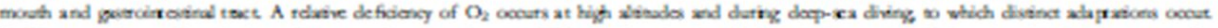

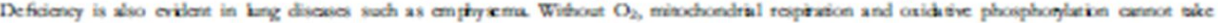

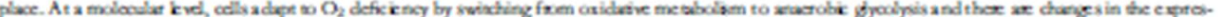

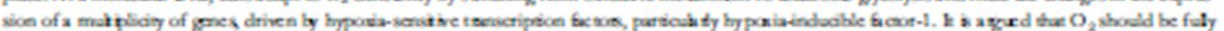

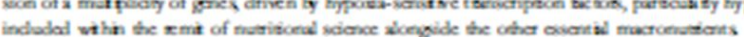

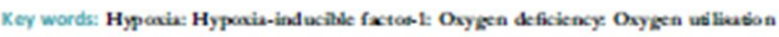




\section{Thermogenic defect in pre-obese $o b / o b$ mice}

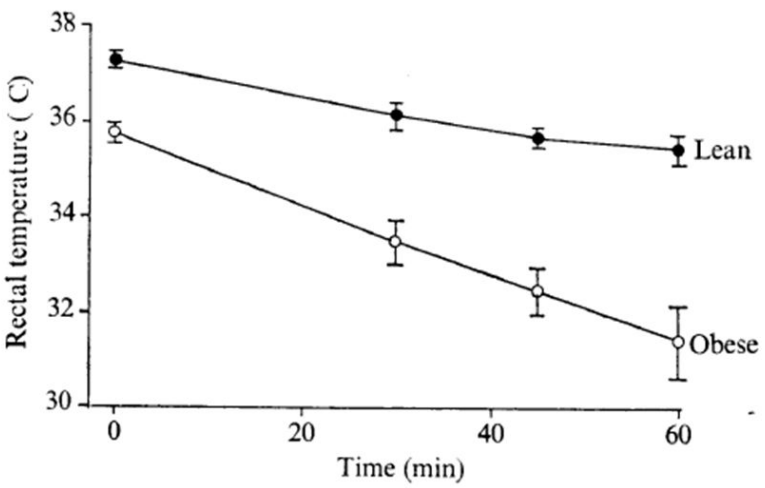

Fig. 1 Rectal temperatures of 17-d-old mice in response to an environmental temperature of $4^{\circ} \mathrm{C}$. Mice were removed from the nest and their initial temperature was taken by inserting a thermocouple (diameter $<1 \mathrm{~mm}$ ) $10 \mathrm{~mm}$ into the rectum; the thermocouple was attached to a Comark 3001 digital thermometer. Each mouse was individually caged and immediately transferred to a $4^{\circ} \mathrm{C}$. were taken periodically. The results are expressed as thements we means s.e.m. for 39 lean animals $(0)$, and for 16 animals that were subsequently found to carry the $o b / o b$ genotype $(0)$. At each time the temperature difference between the two groups was statistically significant, $P<0.001$, on the basis of a Students' $t$ test.

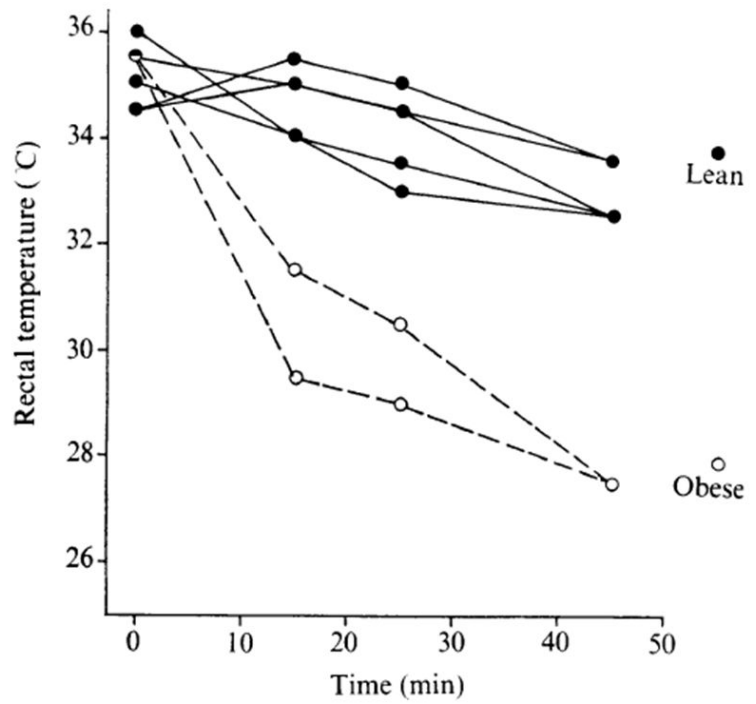

Fig. 2 Rectal temperatures of a litter of 12 d-old mice in response to an environmental temperature of $15 \mathrm{C}$. Experimental details are the same as in Fig. 1. The animals fell into two groups, those subsequently found to be ob/ob $(\bigcirc)$ and those found to be lean ( 
Subject: Decision for manuscript 2017EJCN1124

From: <ejcn@nature.com>

Date: 19/12/2017 09:58

To: $<$ p.trayhurn@liverpool.ac.uk>

Manuscript Number: 2017EJCN1124

Title: A basic scientist's odyssey in nutrition

Corresponding Author: Prof Trayhurn

Dear Prof Trayhurn,

I am very pleased to inform you that your above mentioned manuscript has now

been accepted for publication in the European Journal of Clinical

Nutrition.

Please download the necessary forms depending on whether your paper is to be published as Open Access or standard, and email (EJCN@nature.com) or fax (+44 (0)20 7138 2552) back to our office within 48 hours. Your manuscript cannot be sent to production until these forms are received.

- Standard publication:

\section{Licence to Publish form}

- Government employees from the United Kingdom, United States, and Canada are required to sign a government employee License to Publish form.

2. If any of the authors on this article are from MIT, the University of Rhode Island, Princeton University, UCSF, Georgia Tech, California Institute of Technology, or Harvard University (Faculty of Arts and Sciences), and you are not paying for Open Access, please return the License to Publish form with a waiver from the institution of every affected author.

\section{- Open Access:}

\section{Licence to Publish Open Access form}

- Government employees from United Kingdom, United States, or Canada need to return the relevant Government Employee Open Access License to Publish form.

\section{Open Access Article Processing Charge form.}

- Please note that if you have opted to make your paper Open Access, there will be no additional colour charges. 